\title{
The Impact of Islamic Banking on Entrepreneurial Motivation, Firm Competitiveness and Performance in South African Small and Medium Enterprises
}

\author{
Ms Progress Hove \\ DTech candidate, Department of Logistics, Vaal University of Technology \\ Private Bag X021, Vanderbijpark, 1900 \\ Email: proggyhove@gmail.com \\ Mr Kin Sibanda \\ University of Fort Hare \\ Private Bag X1314, Alice, 5700 \\ Dr. David Pooe \\ Head of Department, Department of Logistics \\ Private Bag X021, Vanderbijlpark, 1900 \\ Email: pooe@vut.ac.za
}

Doi:10.5901/mjss.2014.v5n15p165

\begin{abstract}
Through its commonly recognised characteristics of zero interest loans and the sharing of profits, losses and risks Islamic banking is rapidly gaining importance in the contemporary business world. Yet, there is little empirical evidence that point to the impact of Islamic banking on the key economic drivers such as entrepreneurship, competition and performance of small and medium enterprises (SMEs) particularly in South Africa. Hence, this paper examined the impact of Islamic banking on entrepreneurial motivation, firm competitiveness and business performance of SMEs in South Africa. To this end, a survey was carried out and data was gathered by means of questionnaires on a sample of 150 SME owners/managers in the Eastern Cape and Gauteng Provinces. Structural equation modelling was employed to analyse data using the Smart Partial Least Squares (PLS) software. The findings reveal that Islamic banking has a positive impact on both entrepreneurial motivation and firm competitiveness while the relationship between entrepreneurial motivation and the business performance of SMEs was found not to be significant. Furthermore, the study found that firm competitiveness has a highly significant and strongly positive impact on business performance of SMEs. In view of these findings, the paper concludes with some implications and policy recommendations for both the banks and the government.
\end{abstract}

\section{Introduction}

Islamic banking has recently sprouted as a unique service for both Muslims and Non-Muslims world over, and a solution to the start-up capital challenge for SMEs worldwide. According to Aburime and Alio (2009), Islamic banking is a banking system or activity that complies with the Islamic law Shariah principle and guided by the Islamic economics whose key objective is premised on the notions of social justice and equitable distribution of resources. Thus, in the contemporary business world, the concept of Islamic banking has been developed on the basis of providing zero interest loans as well as sharing of profits and losses, owning of goods, involvement in the process of trading, leasing and construction contracts between the investor and the entrepreneur (Buksh, 2006). Over the last three decades, the Islamic banking concept has gained popularity worldwide owing to the major opportunities it offers, such as the diversification of the investor base and its ability to attract and increase a country's investment (Osman 2012; Ahmad, 2008). This is evident from the significantly high compound annual growth rate recorded in the Islamic banking industry during the years of the global economic meltdown between 2006 and 2009 (Reuters, 2010)

Islamic banking was introduced in South Africa some two decades ago. Currently, in South Africa Albaraka Bank which has been operational since 1989 is one bank that served as the pioneer of Islamic banking in the country and is part of one of the largest Islamic Banking groups worldwide. (Suleman, 2011; Albaraka Bank, 2011) So far has there is one Islamic bank, supported by two conventional banks, ABSA and FirstRand National Bank (FNB), which offer Islamic 
banking products and services over and above the conventional banking products. Given the zero interest on loans requirement of the Shariah principle in the Islamic banking system, the attraction by banks such as ABSA and FNB remains of interest.

According to Suleman (2011), there are two ways banks can earn profits in the Islamic banking system. Firstly, through the profit and loss sharing method, where the bank shares in the profits, losses and risks of the business with the client. Secondly, banks such as ABSA and FNB in South Africa can also earn profits under the Islamic banking system by buying assets on behalf of their clients and reselling these to their clients at a profit (Suleman 2011). Despite the rise in importance and implementation of the Islamic banking system in South Africa, SMEs continue to weaken and perform poorly (Hove \& Chikungwa, 2013). Hence, this study seeks to uncover the impact of Islamic banking's zero interest loans as well as profit and loss sharing systems on the entrepreneurial motivation of SME owners/managers in South Africa.

The contribution of SMEs towards employment creation, productive utilization of capital and financial resources, wealth creation, innovation development and poverty alleviation worldwide has become indisputable (Memba, Gakure, Karanja, 2012; Aremu \& Adeyemi, 2011) Yet, for SMEs access to capital remains the most commonly cited challenge mainly due to lack of collateral security to secure bank loans for startup capital (Hove \& Chikungwa, 2013; Fatoki \& Garwe, 2010). For those that manage to secure the bank loans, it is reported that their growth get stunted, and thus perform poorly as a result of the interests charged on their bank secured loans for startup capital (Fatoki \& Garwe, 2010).

Despite the fact that Islamic banking has existed for two decades in South Africa, the empirical evidence on the impact of Islamic banking on SMEs on the whole, remains scant. Previous studies that have sought to investigate Islamic banking issues focused mainly on developing the banking products for Islamic corporate clientele (Ackermann \& Jacobs, 2008), consumer awareness and usage of Islamic banking products in South Africa ( Hafsa Orhan Åström, 2013; Saini, Bick \& Abdulla 2011) and the legislative challenges (Suleman 2011). Rarely does one find studies that have followed up to report on the impact of these Islamic banking products on entrepreneurship motivation, firm competitiveness and SME performance. More so, extant literature has linked entrepreneurial motivation to strategic orientations and business performance (Deshpande, Grinstein, Kim \& Ofek, 2013); resistance to change and growth of small firms (Gray 2002).

In addition, all these studies were conducted developed nations such as the United States of America (Deshpande et al., 2013; Shane, Locke \& Collins 2003) and the United Kingdom (Gray 2002). Little remains known on the effects of Islamic banking on entrepreneurial motivation, firm competitiveness and performance of SMEs both in developed and developing countries. Hence, this paper seeks to investigate the impact of Islamic banking on entrepreneurial motivation in South African SMEs, their competitiveness as well as financial and marketing performance. The remainder of the paper is structured as follows: literature review, which includes the theoretical and empirical review. The methodology section, findings as well as the conclusions and recommendations follow.

\section{Literature Review}

This section reviews the previous evidence on the four research constructs employed in this paper.

\subsection{Islamic Banking}

As earlier noted, Islamic banking refers to a system of banking or activity that is consistent with the Shariah principles of the Islamic law and works under the guidance of Islamic economics (Aburime \& Alio, 2009). The main difference between the Islamic banks and the conventional banks is that while the latter is based on the conventional interest-based principle, the former follows the principle of interest-free and profit and loss sharing (PLS) in performing their business as intermediaries (Ariff, 1988). Thus, Islam banking is characterized by interest free loans, low consumer lending and profit and loss sharing. With the interest-free loans, banks are prohibited from paying or earning interest on loaned funds. As such, these banks are only allowed to collect the amount equivalent to the loaned principal amount (Aburime \& Alio, 2009). Interest payments are a financial burden especially to small firms as they constrain their performance or achievement of full employment (Aburime \& Alio, 2009). Under the term of Islamic PLS, the relationship between borrower, lender and intermediary are rooted on financial trust and partnership (Yudistira, 2004).

\subsection{Entrepreneurial motivation}

Entrepreneurial motivations refer to the desire or tendency to organize, manipulate and master organizations, human beings or ideas as quickly and independently as possible (Johnson, 1990) Entrepreneurial motivation encompasses the entrepreneur's independence motive, increase of wealth and necessity motive (Hessels, van Gelderen \& Thurik, 2008). 
The independence motive refers to the share of an entrepreneur's participation in the early stages of entrepreneurship activities with a motive of gaining independence and becoming their own boss at work (Hessels et al. 2008).

The increase of wealth motive refers to the share of an entrepreneur's participation in the early stages of entrepreneurship activities driven by their need for achievement, and with a motive to increase their wealth (Hessels et al. 2008). Praag and Cramer (2001) found that people would become entrepreneurs if the expected rewards surpass the wages of employment. Based on the above, this paper posits that the use of Islamic banking as a source of start-up capital, given its zero interest loans and the profit and loss sharing, should enable entrepreneurs (SME owners/managers) who find themselves with no other work options, or desiring to increase their wealth and or desiring independence and becoming their own bosses, to indeed run their own businesses successfully. This is based on the assumption that the absence of interest burdens on the source of capital should be an entrepreneurial motivating factor. Thus, this paper posits that:

H1: Islamic banking has a positive impact on entrepreneurial motivation of SMEs in South Africa.

\subsection{Firm competitiveness}

Firm competitiveness refers to the ability of a firm to outweigh their rivals because of certain competitive advantages that accrue to them either in the form of minimised costs and maximised business opportunities. There are many sources of competitive advantages for firms. In this study, Islamic banking is considered to be one such source of competitive advantage. This paper argues that if entrepreneurs (SME owners/managers), obtain Islamic banking loans, which are interest free, the absence of interest payment obligation, will reduce the overall costs of the small firms, and make them gain a competitive edge over their competitors using the conventional bank loans that are interest bearing. Thus, this paper hypothesizes that:

H2: Islamic banking has a positive impact on firm competitiveness of SMEs in South Africa.

\subsection{SMEs' Business Performance}

According to Melville, Kraemer and Gurbaxani (2004) business performance refers to how the aggregate technologyenabled performance impacts across all firm activities, such as cost reduction, revenue enhancement, and competitiveness. Vorhies and Morgan (2005) advocate that, despite the general acknowledgement that strong firm capabilities enhance a firm's business performance, a lot of inconclusiveness still exists on the measurement of a firm's business performance. As such some studies have measured marketing performance as part of firm performance (Homburg \& Pflesser, 2003; Hooley, Greenley, Cadogan, \& Fahy, 2005; Wong \& Merrilees, 2007. However, this paper measures the business performance as a uni-dimensional construct using the following research items: profit growth, sales volume, growth and market share and average profit. Therefore, in this study, SME business performance encompasses sales volume, sales growth, average profit, profit growth and market share based on the owners/managers assessment of their firm, relative to those against which they compete. In light of the above, the paper posits the following:

H3: Entrepreneurial motivation has a positive impact on business performance of SMEs in South Africa.

H4: Firm competitiveness has a positive impact on business performance of SMEs in South Africa.

All the above hypotheses are summarized in Figure 1 below:

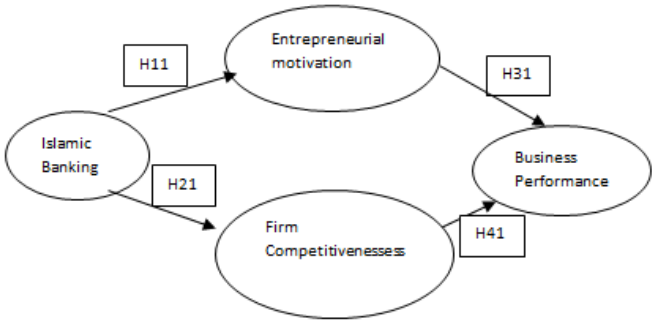

Figure 1: The conceptual model

Figure 1, shows the four hypothesised relationships in this paper. Islamic banking is the antecedent variable, while entrepreneurial motivation and firm competitiveness are the mediators, and business performance is the outcome variable. 


\section{Research Methodology}

\subsection{Sample and data collection}

This paper employed a survey that involved the collection of primary data from a total of 150 SME owners/managers in both the Eastern Cape and Gauteng Province. This was done with the intention of generalising the results to the wider population of South Africa and the developing nations at large. The questionnaire was designed so as to allow the performance of the Confirmatory Factor Analysis Indices (CFAl), such as the Chi-Square/Degree of Freedom (CS/DF), the Comparative Fit Analysis (CFA) and the Incremental Index of Fit (IIF).

The target population for the study were both Muslim and non-Muslim SME owners/managers in Eastern Cape's King Williams town and Alice, and Gauteng's Vanderbijpark and Vereeniging. Convenient sampling was employed, to minimise costs and also to get a balanced opinion on the research topic, given the complex nature of Islamic banking. A total of 150 SME owners/managers were surveyed as the respondents regardless of their religious beliefs.

\subsection{Measurement Instrument and Questionnaire Design}

Research scales were operationalised on the basis of previous work. Proper modifications were made in order to fit the current research context and purpose. "Islamic banking" was measured using eight items adapted from (Aburime \& Alio 2009, Buksh 2006). "Entrepreneurial motivation" was measured using seven adapted items from (Hessels et al. 2008). "Firm competitiveness" was measured using seven items adopted from (Hove 2012). Lastly, "Business performance" was measured using five items adapted from (Wong \& Merrilees 2007; Hove 2012). All the measurement items were measured on a five-point Likert- scale that was anchored by $1=$ strongly disagree to $5=$ strongly agree to express the degree of agreement.

\subsection{Respondent Profile}

Table 1 presents the description of the SME owners/managers who participated in this study's survey. These SME owners/managers were asked to report their demographic information, including gender, age, religion and education. The respondents were predominantly males (58\%), with $42 \%$ females. $60 \%$ of the SME owners/managers were aged 30 and below, $32 \%$ ranged between 31 to 60 years while $8 \%$ were aged above 60 years. Eighty percent $(80 \%)$ of the surveyed SMEs were owned by Muslims while $20 \%$ belonged to non-Muslims. Fifty percent $(50 \%)$ of the SME owners/managers had high school certificates, $40 \%$ had a diploma or certificate while $10 \%$ had a university degree or post graduate degree.

Table 1: Sample Demographic Characteristics

\begin{tabular}{|l|c|c|}
\hline Gender & Frequency & Percentage \\
\hline Male & 87 & $58 \%$ \\
\hline Female & 63 & $42 \%$ \\
\hline Total & 150 & $100 \%$ \\
\hline Age & Frequency & Percentage \\
\hline$\leqq 30$ & 90 & $60 \%$ \\
\hline $31-60$ & 48 & $32 \%$ \\
\hline$>60$ & 12 & $8 \%$ \\
\hline Total & 150 & $100 \%$ \\
\hline Religion & Frequency & Percentage \\
\hline Muslim & 120 & $80 \%$ \\
\hline Non-Muslim & 30 & $20 \%$ \\
\hline Total & 150 & 100 \\
\hline Education qualification & Frequency & Percentage \\
\hline High school certificate & 75 & $50 \%$ \\
\hline Diploma/certificate & 60 & $40 \%$ \\
\hline Degree/post grad degree & 15 & $10 \%$ \\
\hline Total & 150 & 100 \\
\hline
\end{tabular}




\section{Data Analysis and Results}

A structural equation modelling (SEM) technique utilising Smart Partial Least Squares (PLS) statistical software was employed to test the hypothesised relationships between Islamic banking, entrepreneurial motivation, firm competitiveness and business performance of SMEs. A Partial Least Squares approach is a structural equation modelling (SEM) approach that is prediction-oriented and variance-based, and is based on a few assumptions about the distribution of the variables (Liljander, Polsa \& van Riel, 2009). Contrary to the more conventional maximum likelihood (ML) SEM techniques such as LISREL (Joreskog \& Sorbom, 2006) and AMOS (Byrne 2001), Smart PLS requires relatively few observations. As such, the Smart PLS was more appropriate and befitting to this study given that the sample size of 150 SME owners/managers used in this paper was relatively small.

\subsection{Measurement model}

This paper primarily employed the composite reliability (CR) and Cronbach's Alpha values to measure construct measurement reliability. In addition, convergent validity was measured using items with loadings of more than 0.5 on their respective (a priori) constructs (Chinomona, 2013). Discriminant validity was measured using the average variance extracted (AVE) values and ensuring that there were no significant inter-research variables cross-loadings (Chin, 1998). This paper performed a confirmatory factor analysis (CFA) and estimated the structural equation model (SEM) using Smart PLS data analysis software. The CFA results are reported in Table 2 and Figure 2, while the SEM results are presented in Table 4 and Figure 2.

Table 2: Accuracy Analysis Statistics

\begin{tabular}{|c|c|c|c|c|c|c|c|c|}
\hline \multicolumn{2}{|c|}{$\begin{array}{l}\text { Research } \\
\text { Construct }\end{array}$} & $\begin{array}{l}\text { LV Index } \\
\text { Value }\end{array}$ & $\begin{array}{l}\text { R-Squared } \\
\text { Value }\end{array}$ & $\begin{array}{l}\text { Cronbach's } \alpha \\
\text { value }\end{array}$ & $\begin{array}{l}\text { C.R. } \\
\text { Value }\end{array}$ & $\begin{array}{l}\text { AVE } \\
\text { Value }\end{array}$ & Communality & $\begin{array}{l}\text { Factor } \\
\text { Loading }\end{array}$ \\
\hline \multirow{8}{*}{ IS } & IS 1 & \multirow{8}{*}{3.591} & \multirow{8}{*}{0.000} & \multirow{8}{*}{0.810} & \multirow{8}{*}{0.858} & \multirow{8}{*}{0.435} & \multirow{8}{*}{0.435} & 0.683 \\
\hline & IS 2 & & & & & & & 0.731 \\
\hline & IS 3 & & & & & & & 0.620 \\
\hline & IS 4 & & & & & & & 0.711 \\
\hline & IS 5 & & & & & & & 0.626 \\
\hline & IS 6 & & & & & & & 0.631 \\
\hline & IS 7 & & & & & & & 0.461 \\
\hline & IS 8 & & & & & & & 0.767 \\
\hline \multirow{7}{*}{ EM } & EM 1 & \multirow{7}{*}{4.221} & \multirow{7}{*}{0.147} & \multirow{7}{*}{0.917} & \multirow{7}{*}{0.933} & \multirow{7}{*}{0.668} & \multirow{7}{*}{0.668} & 0.873 \\
\hline & EM 2 & & & & & & & 0.840 \\
\hline & EM 3 & & & & & & & 0.838 \\
\hline & EM 4 & & & & & & & 0.863 \\
\hline & EM 5 & & & & & & & 0.781 \\
\hline & EM 6 & & & & & & & 0.746 \\
\hline & EM 7 & & & & & & & 0.771 \\
\hline \multirow{7}{*}{ FC } & FC 1 & \multirow{7}{*}{3.713} & \multirow{7}{*}{0.346} & \multirow{7}{*}{0.774} & \multirow{7}{*}{0.833} & \multirow{7}{*}{0.453} & \multirow{7}{*}{0.453} & 0.614 \\
\hline & FC 2 & & & & & & & 0.767 \\
\hline & FC 3 & & & & & & & 0.729 \\
\hline & FC 4 & & & & & & & 0.712 \\
\hline & FC 5 & & & & & & & 0.683 \\
\hline & $\mathrm{FC} 6$ & & & & & & & 0.652 \\
\hline & FC 7 & & & & & & & 0.040 \\
\hline \multirow{5}{*}{ BP } & BP 1 & \multirow{5}{*}{3.600} & \multirow{5}{*}{0.463} & \multirow{5}{*}{0.811} & \multirow{5}{*}{0.870} & \multirow{5}{*}{0.576} & \multirow{5}{*}{0.576} & 0.623 \\
\hline & $\mathrm{BP} 2$ & & & & & & & 0.729 \\
\hline & $\mathrm{BP} 3$ & & & & & & & 0.880 \\
\hline & $\mathrm{BP} 4$ & & & & & & & 0.842 \\
\hline & $\mathrm{BL} 5$ & & & & & & & 0.691 \\
\hline
\end{tabular}

Note: IS = Islamic Banking; EM = Entrepreneurial Motivation; FC = Firm Competitiveness; BP=Business Performance C.R.:

Composite Reliability; AVE: Average Variance Reliability

* Scores: 1 - Strongly Disagree; 2 - Disagree; 3 - Neutral; 4 - Agree; 5 - Strongly Agree 
As previously noted, composite reliability (CR) and the Cronbach's alpha values were used to assess the reliability of the four research constructs measures in this paper. The CR values ranged from 0.833 to 0.933 while the Cronbach's alpha values ranged between 0.774 and 0.917 (see Table 2) - all these measures were above the recommended acceptable value of 0.7 , thereby confirming the reliability of the four construct measures (Nunnally \& Bernstein 1994).

As aforementioned, convergent validity was assessed by checking whether individual factor loadings for each corresponding research construct were above the recommended value of 0.5 (Anderson \& Gerbing 1988). As can be seen in Table 2, all the individual factor loadings for the four research constructs (except for IS7=0.46 and FC7=0.04) ranged between 0.61 and 0.88 , which is above the recommended threshold of above 0.5 . Thus, it can be concluded that the majority of the measurement items used to explain the four research constructs of this paper, explained more than $60 \%$ of the four variables of Islamic banking, entrepreneurial motivation, firm competitiveness and business performance in SMEs.

Moreover, as earlier noted, the existence of discriminant validity measurement items was assessed using the average variance extracted (AVE) values of more than 0.5 (Fornell \& Larcker, 1981). As shown in Table 2, all the AVE values in this paper ranged from 0.44 to 0.67 . However, to guarantee sufficient discriminant validity between the research constructs, the square root of the AVE of each factor is required to exceed the correlations between that factor and all other factors (Fornell \& Larcker 1981). In this study, the squared roots of AVE ranged from 0.659 to 0.817 , thereby exceeding the correlations between the four constructs which ranged between 0.251 and 0.671 (see Table 3). This further confirms the existence of discriminant validity. All in all, these results confirm the reliability and validity of the construct measurements used.

Table 3: Inter-Construct Correlation Matrix

\begin{tabular}{|l|c|c|c|c|}
\hline \hline Research Constructs & IB & EM & FC & BP \\
\hline Islamic Banking (IS) & 1.000 & & & \\
\hline Entrepreneurial Motivation (EM) & 0.277 & 1.000 & & \\
\hline Firm Competitiveness (FC) & 0.671 & 0.251 & 1.000 & \\
\hline Business Performance (BP) & 0.656 & 0.383 & 0.588 & 1.000 \\
\hline \hline
\end{tabular}

Note: IS = Islamic Banking; EM = Entrepreneurial Motivation; FC = Firm Competitiveness; BP=Business Performance

Unlike Amos and Lisrel, Smart PLS software has been criticised for its failure to provide the goodness-of-fit measures for the full path model. Thus, the Smart PLS only provides the $\mathrm{R}^{2}$ values for the dependent variables. However, goodness-offit can be calculated using a global goodness-of-fit method which takes into account both the quality of measurement and the structural model, as proposed by Amato, Vinzi and Tenenhaus (2004). Using the formula:

Goodness-of-fit $=\sqrt[2]{\left(\text { average of all AVE values } * \text { average of all } R^{2}\right.}$;

$=\sqrt[2]{0.533 * 0.239}$

$=0.36$

The calculated global goodness-of-fit $(\mathrm{GoF})$ is 0.36 and equals the recommended goodness-of-fit threshold of 0.36 suggested by Wetzels, Odekerken-Schröder and van Oppen (2009). Therefore, it can be conclude that the research model provides an overall goodness-of-fit.

Figure 2 and Table 4 as well as sections after provide the hypotheses test results. 


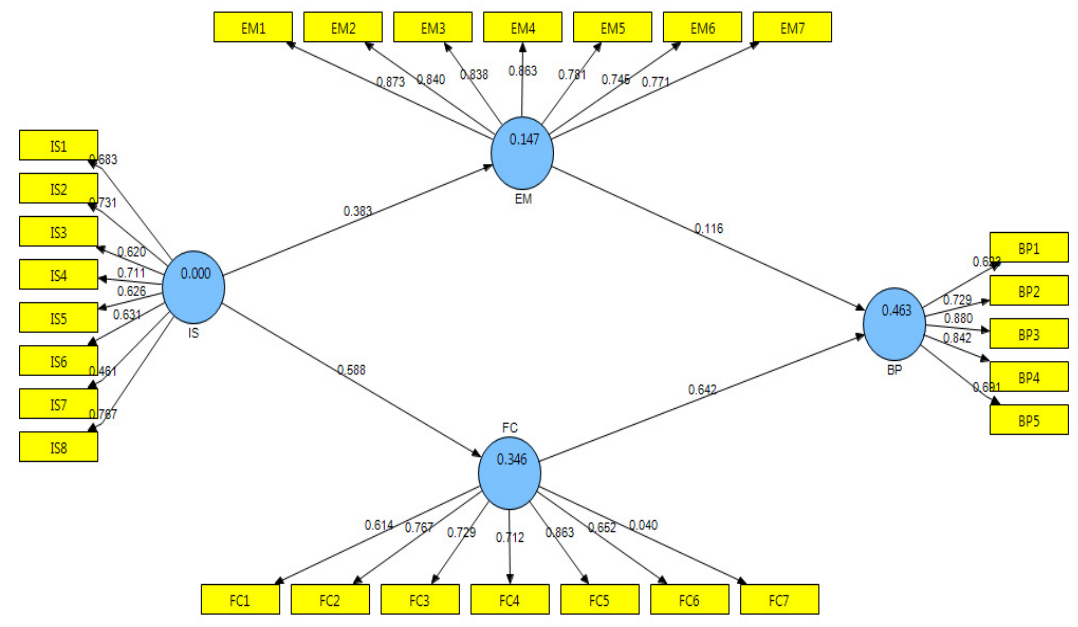

Note: IS = Islamic Banking; EM = Entrepreneurial motivation; FC = Firm competitiveness; $\mathrm{BP}=$ Business Performance

Figure 2: Measurement and Structural Model Results

Table 4: Results of Structural Equation Model Analysis

\begin{tabular}{|l|c|c|c|c|}
\hline \hline Proposed Hypothesis Relationship & Hypothesis & Path Coefficients & T-Statistics & Rejected / Supported \\
\hline Islamic Banking (IB) $\rightarrow$ Entrepreneurial Motivation (EM) & H1 & 0.383 & 4.371 & Supported \\
Islamic Banking (IB) $\rightarrow$ Firm Competitiveness (FC) & H2 & 0.588 & 10.909 & Supported \\
Entrepreneurial motivation (EM) $\rightarrow$ Business Performance (BP) & H3 & 0.116 & 1.909 & Not Supported \\
Firm Competitiveness (FC) $\rightarrow$ Business Performance (BP) & H4 & 0.642 & 13.442 & Supported \\
\hline \hline
\end{tabular}

Note: IB = Islamic Banking; EM = Entrepreneurial motivation; FC= Firm Competitiveness; BP = Business Performance.

\subsection{H1: Islamic Banking has a positive impact on SMEs entrepreneurial motivation}

A positive and significant linear relationship was posited between the adoption of Islamic banking as a source of startup capital and entrepreneurial motivation of SMEs. SEM results that validate or invalidate this relationship are shown in Figure 2 and Table 4 above. Figure 2, reveals a path coefficient of 0.383 for the posited linear relationship between Islamic banking and entrepreneurial motivation. The path coefficient of 0.383 is greater than the recommended path coefficient threshold of 0.2 , hence validating the posited positive impact of Islamic banking on entrepreneurial motivation in SMEs. Table 4 shows a T-statistic value of 4.371 for the linear relationship between Islamic banking and entrepreneurial motivation. The T-statistic of 4.371 exceeds the acceptable threshold of 2.0 (Chinomona 2013), hence, indicating that Islamic banking has a significant and positive impact on entrepreneurial motivation of SME owners/managers. Therefore, the results in Table 4 and Figure 2 validate $\mathrm{H}_{1}$ since the two criteria of significance and positive path coefficient are met. As hypothesised, the findings of this study suggest that the availability of Islamic zero interest loans as a source of start-up capital to SMEs motivates the SME owners to achieve independence, become their own bosses, as it were. These findings are consistent with the common wisdom, that small firms, because of lack of collateral security to allow them to secure the conventional banks' interest bearing loans, prefer zero interest loans. Therefore, this study strongly validates and supports that Islamic banking has a positive impact on entrepreneurial motivation of SMEs.

\subsection{H2: Islamic Banking has a positive impact on firm competitiveness of SMEs}

This paper hypothesised a positive and significant impact of Islamic banking on firm competitiveness of SMEs. As 
aforementioned, the SEM results that validate or invalidate this relationship are shown in Figure 2 and Table 4. Figure 2 , shows a path coefficient of 0.588 for the posited linear relationship between Islamic banking and firm competitiveness. The path coefficient of 0.588 exceeds the recommended path coefficient threshold of 0.2 , hence validating the hypothesised positive impact of Islamic banking on firm competitiveness of SMEs. Table 4, reports a T-statistic value of 10.909 for the linear relationship between Islamic banking and firm competitiveness of SMEs. The T-statistic of 10.909 is greater than the recommended threshold of 2.0. This shows that Islamic banking has a significant and positive impact on firm competitiveness of SMEs. Thus, the findings in Table 4 and Figure 2 validate $\mathrm{H}_{2}$ since the two criteria of significance and positive path coefficient are met. The findings suggest that the availability of Islamic zero interest loans as a source of start-up capital to SMEs gives them a competitive edge over their rivals using interest bearing loans as sources of startup capital. Consequently, this study strongly validates and supports that Islamic banking has a positive impact on firm competitiveness of SMEs.

\subsection{H3: Entrepreneurial motivation has a positive impact on business performance of SMEs}

This paper also hypothesised a positive and significant impact of entrepreneurial motivation on business performance of SMEs. As previously noted the SEM results that validate or invalidate this relationship are shown in Figure 2 and Table 4. Figure 2, reveals a path coefficient of 0.116 for the posited positive impact of entrepreneurial motivation on business performance of SMEs. The path coefficient of 0.116 falls below the recommended path coefficient threshold of 0.2 , hence invalidating the posited positive impact of entrepreneurial motivation on business performance of SMEs. Table 4, presents a T-statistic value of 1.909 for the linear relationship between entrepreneurial motivation and business performance of SMEs. The T-statistic of 1.909 also falls below the recommended threshold of 2.0. The findings in Table 4 and Figure 2 invalidate $\mathrm{H}_{3}$ since both criteria for validating the hypothesis are not met. Therefore, this paper fails to validate and support the hypothesis that claims that entrepreneurial motivation has a positive impact on business performance of SMEs.

\subsection{H4: Firm competitiveness has a positive impact on business performance of SMEs}

This paper further posited that firm competitiveness has a positive and significant impact on business performance of SMEs. As shown in Figure 2, the posited relationship between firm competitiveness and business performance of SMEs has a positive path coefficient of 0.642 . The path coefficient exceeds the minimum acceptable and recommended path coefficient threshold of 0.2 , thus validating the posited positive impact of firm competitiveness on business performance of SMEs. Table 4, complements the positive path coefficient in Figure 2, with a T-statistic value of 13.442, which is far above the recommended threshold of 2.0. This implies that firm competitiveness has a highly significant and positive impact on business performance of SMEs. These findings are consistent with previous studies that revealed a positive effect of a firm's competitiveness on the performance of that firm (Hove 2012). Therefore, this paper validates and supports the hypothesis that postulates that firm competitiveness has a positive impact on business performance of SMEs.

\section{Conclusions and Recommendations}

The validation of the hypothesis that claimed that Islamic banking has a positive impact on firm competitiveness (H2) leads to the following recommendation: More financial institutions should consider adopting the Islamic banking interest free loans to finance SME firms that are uncompetitive due to lack of financial resources and also as a result of exorbitant interest charges. This can be helpful to majority of SMEs in South Africa as previous studies confirmed that small and medium enterprises in the country face financial constraints and are hindered by high interest rates on loan offered by banks (Fatoki \& Garwe, 2010). The paper has also postulated that Islamic banking has a positive impact on entrepreneurial motivation (H1), and the findings of this study validated the hypothesis. Based on these findings, this paper recommends that financial institutions should provide Islamic banking start-up capital as a motivation to people with proven entrepreneurial skills. This can involve running business plans competition among young university graduates to finance the best business plan as credit support to young entrepreneurs with bankable projects. Provision of start-up capital is essential as to avoid start up business failures in South Africa due to lack of credit support.

Also based on $\mathrm{H} 1$, it is recommend that banks finance entrepreneurial skills programmes through Islamic interest free loans targeting both existing and potential business owners. The equipping of SME business owners with relevant entrepreneurial skills increase the chances of success of the firms. Most SME business in South Africa fail due to lack of 
relevant entrepreneurial skills (Hove, 2013). Based on H4, it is recommended that financial institutions in South Africa target SMEs that seek to boost business performance through gaining market share from competitors through affordable Islamic banking financial services. Large businesses enjoy economies of scale giving them unfair advantage over SMEs. The provision of interest free Islamic banking loans to SMEs is likely to improve their competitiveness and gain market share from large businesses.

Finally, as a leading policy maker, government should promote the offering of Islamic banking services by financial institutions to SMEs. This can be through taking a leading role by offering such financial services through quasigovernment financial institutions or opening a new bank that specialises in Islamic banking. The government can also encourage private banks to offer Islamic banking services through targeted regulatory incentives like relaxation of tax policies as well as taking government financial services business to banks that comply with the requirement.

\section{Limitations and Future Research Direction}

Although this study makes significant contributions to both academia and practice, the research has its limitations. First and most significantly, the current study was limited to South Africa's Gauteng and Eastern Cape provinces. For results comparisons and generalisability, subsequent research should contemplate replicating this study in other provinces. Secondly, the study did not investigate the impact of different Islamic banking financial services on the competitiveness, performance and entrepreneurial motivation of SMEs. There is need to investigate the impact of different Islamic banking products rather than blanket package so that financial institutions can offer the most significant products. Finally, the present study did not examine other factors that influence SME business performance and competitiveness like brand involvement, brand experience and brand image. Future studies should focus on other non-financial factors that have a bearing on performance and competitiveness and how they can be linked to the provision of Islamic banking services.

\section{References}

Aburime, U.T. \& Alio F. 2009. Islamic banking: theories, practices and insights for Nigeria. International Review of Business Research Papers, 5(1), 321-335.

Ackermann, P.L.S. \& Jacobs, E. 2008. Developing banking products for Islamic corporate clientele. South African Business Review, 12(1), 67-89.

Ahmad, W. 2008. Islamic Banking in the United Kingdom: Opportunities and Challenges. Kingston Business School: London.

Albaraka Bank. 2011. Albaraka Bank. [Accessed on www.alabaraka.co.za]

Amato S., Vinzi, V. \& Tenenhaus, M. 2004. A global goodness-of-fit index for PLS structural equation modeling, France: Oral Communication to PLS Club, HEC School of Management.

Anderson, J.C. \& Gerbing, D.W. 1988. Structural Equation Modelling in Practice: A Review and Recommended Two Step Approach. Psychological Bulletin, 103 (3), 411-423.

Aremu, M.A. \& Adeyemi, S.L. 2011. Small and medium scale enterprises as a survival strategy for employment generation in Nigeria. Journal of Sustainable Development, 4 (1), 200-206.

Ariff, M. 1988. Islamic Banking. Asian-Pacific Economic Literature, 2, 48-64.

Byne, B.M. 2001. Structural equation modeling with AMOS: Basic concepts, applications, and programming. Mahwah, NJ: Lawrence Erlbaum Associates, Publishers.

Buksh, Z. 2006. Can Islamic banking work in South Africa? Unpublished Dissertation. University of Pretoria.

Chin, W.W. 1998. Issues and opinion on structural equation modelling, MIS Quarterly, 22 (1), 7-16.

Chinomona, R. 2013. Dealers' legitimate power and relationship quality in Gaunxi distribution channel: A social rule system theory perspective. International Journal of Marketing Studies, 5(1).

Deshpande, R., Grinstein A., Kim S.H. \& Ofek, E. 2013. Achievement motivation, strategic orientations and business performance in entrepreneurship firms: How different are Japanese and American founders. International Marketing Review, 30(3), 231-252.

Fatoki, 0.O. \& Garwe, D. 2010. Obstacles to the growth of new SMEs in South Africa: A principal component analysis approach. African Journal of Business Management, 4,729-738.

Fornell, C. \& Larcker, D.F. 1981. Evaluating structural equation models with unobservable variables and measurement error. Journal of Marketing Research, 27, 39-50.

Gray, D. 2002. Entrepreneurship, resistance to change and growth in small firms. Journal of Small Business and Enterprise Development, 9(1), 61-72.

Hafsa Orhan Åström, Z. 2013. Survey on customer related studies in Islamic banking. Journal of Islamic Marketing, 4 (3). 294-305.

Hessels J., Van Gelderen M \& Thurik, R. 2008. Entrepreneurship aspirations, motivations and their drivers. Small Business Economics, 31(3), 323-339.

Homburg, C. \& Pflesser, C. 2003. A multiple-layer model of market-orientated organizational culture: Measurement issues and performance outcomes. Journal of Marketing Research, 37, 449-462. 
Hooley, G.J., Greenley, G., Cadogan, J. \& Fahy, J. 2005. The performance impact of marketing resources. Journal of Business Research, 58(1), 18-27.

Hove, P. 2012. The impact of technological marketing on Porter's competitive forces model and SMEs' performance. Unpublished Dissertation. University of Fort Hare.

Hove, P. \& Chikungwa, T. 2013. Internal factors affecting the successful growth and survival of small and micro agri-business firms in Alice communal area. Journal of Economics, 4(1), 57-67.

Johnson, B.R. 1990. Toward a multidimensional model of entrepreneurship: the case of achievement motivation and the entrepreneur. Entrepreneurship Theory and Practice, Vol. 14 No.3, pp.39-54.

Joreskog, K. \& Sorbom, D. 2006. LISREL 8.50. IL: Scientific Software International Inc., Chicago.

Liljander, V., Polsa, P. \& Van Riel, A. 2009. Modelling consumer responses to an apparel store brand: Store image as a risk reducer. Journal of Retailing and Consumer Services, 16, 281-290.

Melville, N., Kraemer, K. \& Gurbaxani, V. 2004. Information technology and organisational performance: An integrative model of IT business value. MIS Quarterly, 28(2), 283-322.

Memba, S. F., Gakure, W. R. \& Karanja, K. 2012. Venture Capital (VC): It's Impact on Growth of Small and Medium Enterprises in Kenya. International Journal of Business and Social Science, 3(6), 32-38.

Nunnally, J.C. \& Bernstein, I. 1994. Psychometric Theory, 3rd Ed. New York: McGraw-Hill.

Osman, A. 2012. Islamic finance and takaful: capturing the Africa opportunity. [Online]. Available http://www.islamicbankingafrica.megaevents.net. [Accessed on 29 October 2013].

Praag, C.M., Cramer, J.S. 2001. The roots of entrepreneurship and labor demand: individual ability and low risk. Economica, 68 (269), 45-62.

Reuters 2010. Reuters. [Online]. Available http://uk.reuters.com/article/idUKTRE6IE2JD. [Accessed on 29 October 2013].

Saini, Y., Bick, G. \& Abdulla, L. 2011. Consumer awareness and usage of Islamic banking products in South Africa. SAJEMS, 14(3), 298-313.

Shane, S., Locke E.A. \& Collins, C.J. 2003. Entrepreneurial motivation. Human Resource Management Review. 13, 257-279.

Suleman, Y. 2011. The legislative challenges of Islamic banks in South Africa. Unpublished Dissertation. University of Stellenbosch.

Vorhies, D. \& Morgan, N. 2005. Benchmarking marketing capabilities for sustainable competitive advantage. Journal of Marketing, 69(1), 80-94.

Wetzels, M., Odekerken-Schroder, G. \& Van Oppen, C. 2009. Using PLS path modeling for assessing hierarchical construct models: guidelines and empirical illustration. Management Information Systems Quarterly, 33(1), 177-195.

Wong, H. \& Merrilees, B. 2007. Multiple roles for branding in international marketing. International Marketing Review, 24(4), 384-408.

Yudistira, D. 2004. Efficiency in Islamic banking: An empirical analysis of eighteen banks. Islamic Economic Studies, 12 (1), 1-19. 